\begin{abstract}
Beattie V, Goodacre A \& Thomson SJ (2006) International lease-accounting reform and economic consequences: The views of U.K. users and preparers, International Journal of Accounting, 41 (1), pp. 75-103.
\end{abstract}

This is the peer reviewed version of this article

NOTICE: this is the author's version of a work that was accepted for publication in International Journal of Accounting. Changes resulting from the publishing process, such as peer review, editing, corrections, structural formatting, and other quality control mechanisms may not be reflected in this document. Changes may have been made to this work since it was submitted for publication. A definitive version was subsequently published in International Journal of Accounting, [VOL 41, ISS 1 (2006)] DOI:

http://dx.doi.org/10.1016//j.intacc.2005.12.003 
Published in: International Journal of Accounting, 41(1), March 2006, pp. 75-103.

\title{
International lease accounting reform and economic consequences: the views of UK users and preparers
}

\author{
Vivien Beattie*, Alan Goodacre** and Sarah Jane Thomson*** \\ * Professor of Accounting, University of Glasgow \\ ** Professor of Accounting and Finance, University of Stirling \\ ***Lecturer in Accountancy and Finance, Heriot-Watt University
}

Draft date: September 2005

\footnotetext{
* Corresponding author: Vivien Beattie, Department of Accounting \& Finance, 65-73 Southpark Avenue, Glasgow, G12 8LE, UK (e-mail: V.Beattie@accfin.gla.ac.uk)

Acknowledgements

The financial support of the Centre for Business Performance of the Institute of Chartered Accountants in England and Wales and of the Carnegie Educational Trust (for Sarah Jane Thomson) is gratefully acknowledged. The contribution made by the individuals who gave freely of their time in completing the questionnaire is also greatly appreciated. We also thank the anonymous reviewer and the Associate Editor for their constructive comments on the paper.
} 


\title{
International Lease Accounting Reform and Economic Consequences: The Views of UK Users and Preparers
}

\begin{abstract}
In response to perceived difficulties with extant lease accounting standards in operation worldwide, the G4+1 issued a discussion paper which proposes that all leases should be recognized on the balance sheet (ASB, 1999). Leasing is now on the active agenda of the IASB. A major difficulty faced by standard setters lies in overcoming the preparer/user lobbying imbalance and obtaining ex ante evidence on the likely impact of regulatory reform. This paper contributes to the ongoing international debate by conducting a questionnaire survey of UK users and preparers to assess their views on proposals for lease accounting reform and on the potential economic consequences of their adoption. The results, based on 132 responses, indicate that both groups accept that there are deficiencies in the current rules, but they do not agree on the way forward and believe that the proposals would lead to significant economic consequences for key parties. The impact on respondents' views of familiarity with the proposals, level of lease usage, and company size, is also examined.
\end{abstract}

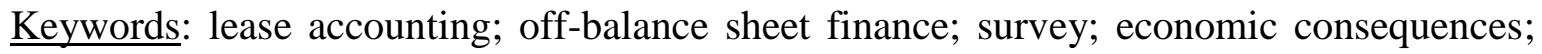
lobbying 


\section{International lease Accounting Reform and Economic Consequences: The Views of UK Users and Preparers}

\section{Introduction}

In many countries, operating leases represent a significant source of finance for many companies, far exceeding the significance of finance leases. For example, it has recently been estimated that, for the top 100 listed UK companies, the median ratio of operating lease liability to debt is 0.11 and the median ratio of operating lease liability to finance lease liability is 6.2 (Beattie et al., 2004). ${ }^{1} \quad$ Internationally, key leasing standards distinguish finance leases from operating leases, finance leases being defined as those which transfer substantially all the risks and rewards of ownership to the lessee. The accounting treatment depends on the lease classification, with only finance leases being capitalized.

Concerns regarding the off-balance sheet nature of operating leases, the different treatment of similar transactions and the 'all or nothing' approach have led many standard-setting bodies to consider treating all leases consistently. This culminated in a G4+1 discussion paper 'Leases: implementation of a new approach' (ASB, 1999), which adopts a 'property rights' perspective and proposes that all leases should be recognized on the balance sheet, rather than just finance leases. ${ }^{2}$ Leasing is now on the active agenda of the IASB and the UK accounting standard-setting body was asked to undertake a project to inform the IASB, which expects to take action in 2006/07 (IASB, 2005). The IASB has tentatively agreed with the G4+1 approach of analyzing the contractual rights and obligations arising from lease contracts (ASB, 2004).

The different accounting treatments have important implications for reported levels of indebtedness and for standard performance measures. Profit margins, return on assets and gearing measures would all be significantly affected if operating leases were required to be recognized on the lessee's balance sheet rather than merely disclosed in a footnote (Imhoff et al., 1991; Beattie et al., 1998; Goodacre, 2003). It is not surprising, therefore, that the G4+1 proposals are controversial and have already generated a significant negative response from groups, in particular lessors and high operating lease use lessees, who fear that there would be major adverse economic consequences. 
Certain major interested parties, such as preparers, audit firms and other groups (here, for example, the lessor group), are well organized to lobby the standard setters to ensure that their group views are heard. However, users are generally a wider, more diverse, less organized group with less focus and often less technical knowledge for lobbying activities. It is widely recognized that a major difficulty faced by accounting standard setters worldwide lies in obtaining the views of users of financial statements (Collins et al., 1996; Jonas and Young, 1998; Herz, 2003).

This paper contributes to the ongoing international debate concerning lease accounting reform by reporting the results of a questionnaire survey sent to users (investment analysts) and preparers (finance directors). The objectives of the research are to elicit and compare the views of both groups on a comprehensive range of issues surrounding lease accounting reform. The issues are: views on accounting standards generally; deficiencies in the current UK standard; the general principles underlying the G4+1 proposals; the specific proposals regarding complex features of lease contracts; economic consequences; alternative proposals; and implementation. The impact on views of three background characteristics is also examined: respondents' declared familiarity with the proposals (for both users and preparers); level of lease usage (preparers only); and company size (preparers only). The study represents policy-relevant ex ante research in support of the standard setting process of the type advocated by Schipper (1994).

To provide some context for the present study, it should be noted that institutional differences are believed to affect corporate financing decisions. As leasing decisions are part of the overall financing decision, it is to be expected that these differences would also impact leasing decisions and hence interested parties' views about lease accounting reform. The UK can be characterized as having a broadly similar financial and legal environment to the US. It has a common law legal system with good investor protection and welldeveloped, liquid financial markets. Bank finance and inter-company ownership relationships play relatively smaller roles than in some countries. The most obvious differences between the UK and US (apart from the relatively great size of the US market in terms of number of companies and market capitalization) relate to tax and bankruptcy codes and the size of the corporate bond market (Rajan and Zingales, 1995). La Porta, et 
al. $(1997,1998)$ consider that a country's legal system is the main determinant of external finance availability.

The remainder of the paper is structured as follows. Section two first provides a brief discussion of the current and proposed methods of accounting for leases. It then reviews three strands of literature relevant to the debate on lease accounting reform: the preparer/user lobbying imbalance; the quality of accounting standards; and various approaches to the assessment of economic consequences. The section ends with the presentation of the specific research questions addressed in the current study. Section three outlines the methods employed, including sampling and data collection procedures. Results are presented in section four. A final section summarizes and concludes.

\section{Literature}

\subsection{Lease accounting: extant regulations and proposals}

The international leasing standard (IAS 17 'Leases') is typical of many extant standards worldwide. It makes a fundamental distinction between finance leases and operating leases, defining a finance lease as one that transfers to the lessee substantially all the risks and rewards of ownership (IASB, 2003). It is treated as an 'in substance' purchase by the lessee and sale by the lessor. An asset is shown on the lessee's balance sheet at the present value of the minimum lease payments and a corresponding liability is recognized. An operating lease is any other lease. The underlying asset appears in the balance sheet of the lessor and the lessee simply recognizes the rental payments as an expense, with additional footnote disclosure regarding total minimum future lease rental commitments, with this commitment being classified into time horizon categories (less than one year, two to five years and more than five years).

The equivalent US standard (SFAS 13), which uses the term 'capital lease' rather than 'finance lease', introduces 'bright lines' into lease classification. It defines a capital lease as one under which any one of the following four conditions is met: (i) the present value at the beginning of the lease term of the payments not representing executory costs paid by the lessor equals or exceeds $90 \%$ of the fair value of the leased asset; (ii) the lease transfers ownership of the asset to the lessee by the end of the lease term; (iii) the lease contains a bargain purchase price; (iv) the lease is equal to $75 \%$ or more of the estimated economic 
life of the leased asset (FASB, 1976). The UK standard (SSAP 21) also includes a bright line classification test. Under SSAP 21, a lease is presumed to be a finance lease if the present value of the minimum lease payments at the inception of the lease amount to substantially all (normally $90 \%$ or more) of the fair value of the leased asset (ASC, 1984). ${ }^{3}$

Bright line rules such as found in the US and UK standards carry the danger of creative compliance (i.e. the use of rules to escape control without actually violating those rules). 'Formalism' in standard setting implies a narrow approach to control (i.e. the use of clearly defined rules), whereas 'anti-formalism' involves the use of principles (McBarnet and Whelan, 1991; 1992; 1999).

In 1996, the G4+1 published a special report entitled 'Accounting for leases: a new approach' (McGregor, 1996). Three fundamental deficiencies in existing lease accounting standards were identified. First, material assets and liabilities arising from 'off-balance sheet' operating lease contracts are omitted. Second, similar transactions do not receive the same accounting treatment since marginal differences in contractual terms can result in one lease being claimed as a finance lease and another as an operating lease. This illustrates the weakness of so-called 'bright line' standards. Third, the 'all or nothing' approach to the capitalization of leased assets does not adequately reflect modern complex transactions. A conceptual approach to lease accounting is advocated, whereby the distinction between finance leases and operating leases is removed. Lessees would recognize as assets and liabilities all material rights and obligations arising under lease contracts.

Three years later, the G4+1 organizations published a discussion paper 'Leases: implementation of a new approach', which develops the approach recommended in the special report (ASB, 1999). It reiterates the view that all leases should be reflected in financial statements in a consistent manner and it explores the principles that should determine the extent of the assets and liabilities to be recognized by lessees and lessors. The discussion paper recommends that, at the beginning of a lease, the lessee recognizes an asset and a liability equivalent to the fair value of the rights and obligations that are conveyed by the lease. This is usually the present value of the minimum payments required by the lease. Subsequently, the lease asset and liability would be treated as fixed 
assets and debt. The other party to the transaction, the lessor, would report financial assets (representing amounts receivable from the lessee) and residual interests (if any) as separate assets. Although lease contracts often include features such as renewal options, contingent rentals and residual value guarantees, the discussion paper considers ways of dealing with these and other features. Essentially, the paper calls for the capitalization of the measurable future benefits and obligations for all lease transactions.

Looking forward, it seems clear that the international convergence of accounting standards is going to happen. A change on one standard is likely to impact on the standards for other jurisdictions. The introduction of International Financial Reporting Standards (IFRS) for listed companies in the European Union occurs in 2005. In the UK, the ASB has stated, in its consultation paper on UK convergence, that it will not replace SSAP 21 with a standard based on IFRS requirements until the IASB completes its leasing project (although in the short term it does propose to adopt IAS 17 disclosure requirements). In the US, FASB agreed with the IASB to work towards the convergence of US GAAP and IFRS at a joint meeting in 2002 (Schipper, 2005).

\subsection{The preparer/user lobbying imbalance}

In recent years, there has been increasing recognition that users' views regarding accounting standards are seriously under-represented. Collins et al. (1996) report that only 14 of the 104 letters of comment to the UK ASB regarding the OFR Discussion Paper were from users, and suggest that this imbalance must be remedied by seeking out users' views explicitly. Jonas and Young (1998) argue that quality in business reporting is being undermined by the systemic problem of insufficient user focus in the process of setting reporting standards. One of the explanations they offer for the under-representation is that the professional background of standard-setters tends to be as preparers/auditors rather than users, making it difficult for them to 'bridge the gap'. More recently, the Chairman of the US standard-setting body (FASB) has suggested that it may be overly influenced by the preparer and auditor communities, identifying the low level of involvement by users as a challenge for the Board (Herz, 2003).

Academic studies that survey attitudes to accounting standards have generally targeted preparers as the respondent group and have been conducted ex post. For example, Hooks 
and van Staden (2004) survey preparers in New Zealand to elicit their views on FRS 15 'Provisions, Contingent Liabilities and Contingent Assets'. Joshi and Ramadhan (2002) survey Bahrainian preparers on issues surrounding IASs. Nixon (1997) surveys UK preparers' views on SSAP 13 (revised) 'Accounting for Research and Development' and an alternative suggested treatment whereby more expenditure would be capitalized. It is notable that views are also elicited regarding the economic consequences of expensing R\&D. Reither (1998) surveys participants at the 1996 AAA/FASB Financial Reporting Issues Conference to establish which standards were viewed as the best and the worst. User surveys have tended to address user needs in terms of the importance of specific information items, whether currently reported or not (for a recent example, see Beattie and Pratt, 2002). Yap (1997) is one of the few studies to investigate users' attitudes to a particular extant standard, specifically the Australian standard on cash flow statements. Dunne et al. (2003) interview users and preparers about FRS 13 'Derivatives and Other Financial Instruments - Disclosures'. There is, however, a dearth of academic research that surveys users' views on specific proposals for regulatory reform.

The need for such research is further indicated by the fact that, of the 59 formal responses to the G4+1 discussion paper received by the ASB, just $3(5 \%)$ were from users or user groups. Based on another simple measure (number of pages of response), users contributed just $7 \%$ of the overall response. Since recent research suggests that the level of other forms of lobbying is highly correlated with the use of formal comment letters (Georgiou, 2004), the absolute differential between the overall level of preparers and users lobbying could be huge.

\subsection{Quality of accounting standards}

The former Chairman of the US Securities and Exchange Commission has identified high quality standards as critical to financial reporting, going on to explain that 'they must result in comparability and transparency, and they must provide for full disclosure' (Levitt, 1998, p.81). Following this, Accounting Horizons published six commentaries, from senior representatives of a range of constituencies, on the attributes of high quality accounting standards (Imhoff, 1998). Interestingly, in Reither's (1998) survey, SFAS 13 'Leases' was voted the worst standard. Explanations given included the following: many obligations that, in substance, are capital, sales-type, or direct financing leases are shown as operating 
leases; conceptually and operationally an accounting nightmare; bright-line rules for lease capitalization result in abuse; and too complicated.

Collins et al. (2002) link empirically the normative qualities reflected in the commentaries with the actual judgments of constituents. Using content analysis, they identify 16 unique characteristics. The particular characteristics of SFAS 13 that led it to be considered the worst standard were found to be lack of economic reality, lack of clarity, lack of implementation guidance and the need for frequent amendment.

\subsection{Economic consequences}

For over two decades, economic consequence arguments have been used by lobbying groups. Economic consequences arise when changes in the information set reported affects a company's cash flows or its distribution (Holthausen and Leftwich, 1983). This can occur in two ways. First, there may be changes in either the behavior of users or the behavior of managers. The latter includes actions to mitigate the expected impact on users, a situation known as 'information inductance' (Prakash and Rappaport, 1977). Second, the company's formal or informal contracts may be affected. The identification and measurement of economic consequences is, however, problematic. Researchers have used four different empirical methods: the analysis of archival accounting data; market-based studies; experimental studies and surveys.

First, the archival method either compares the accounting numbers pre- and post- a change in the accounting rules (an ex post study) or constructs pro-forma accounting statements based on proposed rule-changes and compares these with the statements under extant rules (an ex ante study). In an early ex post study, Abdel-khalik (1981) found that company management responded to the introduction of SFAS 13 by structuring new lease contracts, and renegotiating existing lease contracts, to avoid capitalization of leases. There was evidence that more assets were bought, or constructed, instead of being leased and also evidence of changes in capital structure. Imhoff and Thomas (1988) also examined capital structure changes in response to SFAS 13, documenting a systematic substitution from finance (capital) leases to operating leases and non-lease sources of finance. In an Australian study, Godfrey and Warren (1995) found a similar substitution effect. However, in contrast with the US, companies did not appear to have renegotiated finance 
lease contracts to operating leases. In the UK, Garrod (1989) found that managers reacted to the introduction of SSAP 21 by reducing their non-lease debt prior to first disclosure of their lease information.

There are also several ex ante studies based on accounting numbers, specifically accounting ratios that are used as key performance indicators. Nelson (1963) examined the impact of lease capitalization on the debt-equity ratio of eleven US companies, finding a significant change in the rankings. Ashton (1985) estimated the effect of finance lease capitalization on six ratios for 23 UK companies, finding a significant impact only on the gearing ratio. More recent studies focus on the impact of operating lease capitalization. Imhoff et al. (1991) develop a method for the constructive capitalization of operating leases, using this to estimate the impact on two ratios (return on assets and debt-equity ratio) for 14 US companies. Material differences are found for both high and low operating lease use companies. A subsequent paper found the income effects to be substantial and unpredictable in direction (Imhoff et al., 1997). Beattie et al. (1998) and Goodacre (2003) analyze UK data using the Imhoff et al. (1991) method, adapted to suit the UK setting. Both studies examine nine ratios: profit margin, three return ratios, asset turnover and four gearing measures. Beattie et al.'s (1998) findings, based on 1994 data for 232 industrial and commercial companies, show a significant impact for all ratios except return on capital employed and interest cover. One gearing measure showed a massive $260 \%$ change following capitalization. The findings for the 102 companies in the retail sector were even more marked, with all nine ratios showing a significant change (Goodacre, 2003). Dresdner Kleinwort Benson (1998) examine the impact of operating lease capitalization on 27 large UK retail companies, using a simple multiple of annual operating lease rental obligations. It is reported that 'net debt would be in excess of $100 \%$ of equity market capitalization in many cases'. With the exception of Ashton (1985), which may be subject to sample selection bias, all studies reported significant impacts on ratios. However the major impact is upon risk measures, rather than performance measures.

Second, market-based studies are confined to the ex post study of rule changes, although it can be difficult to separate the impact of the event of interest from that of other confounding events. There is mixed evidence of market price reaction to lease accounting information, and this derives from tests using rather old data (Ro, 1978; El-Gazzar, 1993; 
and Garrod, 1989). There is also little evidence of an impact on market-based risk measures (Abdel-khalik, 1981; Finnerty et al., 1980). Other market-based studies report quite strong evidence that the market already incorporates footnote operating lease disclosures in its assessment of equity risk in both the UK (Beattie et al., 2000) and the US (Bowman, 1980; Ely, 1995; Imhoff et al., 1993). ${ }^{4}$

Third, experimental studies explore how individual users process lease accounting information, in particular, whether they appear to be influenced by whether the information is recognized in the financial statements or merely disclosed in the footnotes to the accounts. The evidence is, however, very mixed (Wilkins and Zimmer, 1983a and 1983b; Munter and Ratcliffe, 1983; Hartman and Sami, 1989; Breton and Taffler, 1995; and Gopalakrishnan and Parkash, 1996; and Wilkins, 1984).

Survey research may also be used to evaluate the impact of rule changes. Surveys can investigate, both ex post and ex ante, the perceptions of a range of interested groups and explore the attitudes and views that underpin changes in behavior. We are aware of only two other surveys of lease accounting rules. Taylor and Turley (1985) investigated the opinions of UK preparers on lease accounting following ED29, the exposure draft that preceded SSAP 21. They found that only a minority of managers believed that internal financing or investment decisions would be significantly affected by the proposed accounting standard. However, managers believed that users' decisions, including risk assessment, were likely to be affected, suggesting that managers' behavior could be influenced by information inductance. Managers also anticipated that future lease contracts would be structured as operating leases to avoid capitalization. ${ }^{5}$ Blake et al. (1995) surveyed a sample comprising participants attending a management development course in Spain (including preparers of accounts and bank analysts). Spanish accounting rules have a more restrictive definition of a finance lease than found elsewhere, requiring that a purchase option exist. The brief questionnaire was limited to several yes/no questions. Preparers generally felt that the finance lease accounting rules would result in operating leases becoming more attractive and that all leases should be accounted for as rental agreements. Bank analysts, however, did not feel that leasing activity would diminish, and a third felt that the definition of a finance lease should be expanded to include some agreements currently classified as operating. 


\subsection{Research questions}

The accounting standards quality literature suggests three broad issues to explore with interested parties: (i) views on the current accounting standard and on the G4+1 proposals for change; (ii) views regarding a range of potential economic consequences; and (iii) factors that may explain the views held.

\section{Methods}

\subsection{Sample selection}

The sample of account preparers was based on the population of industrial and commercial UK listed companies. Industrial and commercial companies were selected on the basis that the majority of their leasing activity is conducted as lessees (financial companies were excluded on the basis that the majority of their leasing activity is conducted as lessors). Listed companies were selected on the basis of their economic significance. The sampling frame used was the UKQI (UK quoted industrials) list on Datastream in June 2000. The questionnaire was sent to finance directors of a systematic sample of one-third (415) of this population. The survey of users was designed to focus on expert users (equity analysts) and to cover both sell-side and buy-side analysts. The user sample was drawn from two sources. First, a systematic sample of 400 financial analysts was selected from a mailing list of the London-based Associate members (totaling 1,640) of the UK Society of Investment Professionals. A further sample of 72 was taken from a listing of leading fund management firms published in CA Magazine (1999).

\subsection{Questionnaire design and administration procedures}

The first stage in designing the questionnaire was to review the (fairly limited) theoretical and empirical literature in the area, including previous surveys. This, together with the ASB (1999) discussion paper, was used to produce a draft questionnaire that was sent out for piloting. The draft questionnaire, accompanied by a covering letter, a set of pilottesting questions and a summary of the new proposals for lease accounting, was mailed to thirteen preparers and key contacts. The pilot questions asked about subject matter, length, layout, instructions for completion and question ordering. Useful comments were received

from several finance directors, the ASB and the Finance \& Leasing Association and the questionnaire content and terminology was revised accordingly. The questionnaire 
generally used closed-form questions and adopted a five-point Likert scale with verbal anchors. In total, the questionnaire was 8 pages long (including covers) and asked for responses to 76 question elements. It was mailed out in 2000 (preparers) and 2001 (users), accompanied by an explanatory covering letter that assured the confidentiality of responses and a one-page summary of the G4+1 proposals. Many standard response-enhancing techniques were adopted: clear questionnaire layout; piloting; covering letter addressed to a specific named individual (all finance director details were individually checked by telephone); covering letters signed individually by researchers; follow-up letters sent approximately 10 and 20 days after the initial request ${ }^{6}$; stamped reply envelopes (rather than reply-paid envelopes); non-respondents asked to return the questionnaire.

\subsection{Background characteristics affecting respondents' views}

In most circumstances, more weight is attached to opinions expressed by knowledgeable individuals. Given the technical, somewhat specialized, nature of lease accounting, it was considered important to check whether the mean response reflects the opinions of those who understand the technicalities. The impact of respondents' self-reported familiarity with the lease accounting proposals on views held was investigated for both groups, by splitting them into 'familiar' and 'less-familiar' sub-groups. ${ }^{7}$

It could be argued that companies with high levels of lease usage will anticipate a greater impact on their financial statements and more significant economic consequences under the G4+1 proposals. To investigate this, the companies of preparer respondents were split into high and low operating lease usage groups based on whether ratio of operating lease rentals/sales fell above and below the median level, respectively.

Preparer responses might also be associated with company size, since large and small companies typically have different financing mixes (Lasfer and Levis, 1998; Bevan and Danbolt, 2002), different negotiating power and different administrative capabilities. Responding companies were split into large and small sub-groups based on median total asset value. ${ }^{8}$ 


\section{Results}

After describing response rates and tests for bias, respondents' views are described under seven headings: accounting standards generally; deficiencies in the current lease accounting standard; general principles of the new proposals; specific issues; economic consequences; lease accounting alternatives; and implementation. In some instances, we posed the same basic question in different ways, to guard against sensitivity to question wording. Where essentially the same responses were obtained, only one form of the question is reported here. Some tables are presented using the logical question order appearing in the questionnaire, while others are ranked based on users' responses. Significant differences (at the 5\% level) in response associated with the three background characteristics identified as being of potential relevance (familiarity with the proposals, lease usage and company size) are reported at the end of each sub-section. ${ }^{9}$

\subsection{Response rates and tests for bias}

For the preparer group, 78 usable responses were received representing a response rate of 19\%. An additional 13 responses were received from those who requested a copy of the questionnaire when replying to a questionnaire on a related topic, ${ }^{10}$ giving a total of 91 usable responses. For the user group, 41 usable replies were received representing a response rate of $9 \%$. These rates are in line with other recent studies involving similar groups (see Beattie and Pratt, 2003, note 13 for a discussion). Given that non-response is a significant, and increasing, problem in the survey method, relatively large initial samples were used to provide a satisfactory absolute number of responses to support meaningful statistical analysis. The reasons given for non-completion suggest that the technical complexity of the lease accounting issue was a significant factor for the user group. ${ }^{11}$

Three tests for response bias were performed, two relating only to the preparer group and the third relating to both respondent groups. ${ }^{12}$ First, responding preparer companies were compared with the population of UKQI companies on the basis of size (measured as total assets); a 2-tail t-test confirmed no difference between the sample and population means, even at the $10 \%$ significance level. Second, responding companies were formed into seven broad industrial groups and a chi-squared test goodness-of-fit test confirmed that the sample companies were distributed similarly to companies in the UKQI population (chisquared $=5.92 ; \mathrm{p}=0.4321)$. 
Finally, the responses of early responders were compared to those of late responders for both groups, on the assumption that late responders are similar to non-responders

(Oppenheim, 1966). ${ }^{13}$ As there were no particularly 'key' questions in the questionnaire, a series of tests (Wilcoxon-Mann-Whitney) was conducted for each of the 74 closed-form question elements. For the preparer group, no significant differences were observed. For the user group, only 6 differences were observed out of 74, which is not indicative of any systematic difference between the early and late respondents.

A further factor that can affect the validity of responses is the suitability of individual respondents, in terms of knowledge about the issues under investigation. For the preparer group, virtually all of the respondents were senior financial personnel likely to be knowledgeable about the lease accounting issue. All of the investment analysts were either active professionally qualified (IIMR members) or active senior fund management personnel, so are likely to be representative of expert investment professional users. There were, however, significant differences between the groups' declared familiarity with the lease accounting proposals, with $65 \%$ of the preparer group 'moderately' or 'very' familiar with the new proposals compared with only $34 \%$ of the user group (difference significant at the $1 \%$ level).

\subsection{Accounting standards generally}

Respondents' views on lease accounting reform may be conditioned by their opinion of accounting standards in general (Taylor and Turley, 1985). Opinions on accounting standards are, therefore, reported in Table 1, panel A. The general need for accounting standards is almost universally supported, however preparers are, not surprisingly, more aware of the compliance burden. ${ }^{14}$ It appears, therefore, that the responses to questions concerning lease accounting are unlikely to be colored by a disagreement with accounting standards in general. Any difference in the perceived burden imposed on companies arising from the existing standard and the new proposals could, however, be an issue. Unsurprisingly, there were no significant differences in response associated with familiarity, operating lease usage or company size.

[Table 1 about here] 


\subsection{Deficiencies in current lease accounting standards}

In the development of high quality accounting standards, new proposals should, in addition to possessing certain other attributes, address a current deficiency (Imhoff, 1998). Respondents agreement with ten suggested deficiencies of SSAP 21, taken mainly from the G4+1 special report, are shown in Table 1, panel B, in descending order of agreement by the user group. Most of the deficiencies also apply to IAS 17, however the questions in rows 1 and 3 relate specifically to the existence of a bright line in relation to lease classification.

Both groups agreed that the current standard was open to manipulation, lacked uniformity, did not portray the substance of transactions, was incomplete, inconsistent and lacked clarity (rows 1-5; 8, 9). It is of note that while users did believe that their decision-making was impaired by these deficiencies, preparers did not (rows 6,7,10). The user group also felt significantly more strongly than the preparer group about the difficulty of estimating the balance sheet impact of operating leases (row 2), and was more concerned about the subjectivity of lease classification (row 10).

The primary deficiency of SSAP 21 identified by both groups (that lease transactions could be deliberately structured for classification as operating leases - row 1) was recognized more keenly by 'familiar' preparers ('familiar' group mean $=4.26$; 'less familiar' group mean $=3.82$ ). There were no other significant differences.

\subsection{Lease accounting proposals: general principles}

The approach in the G4+1 discussion paper is grounded in the definitions of assets and liabilities and seeks to improve information for users' decision-making. The general principles focus on recognizing the substance of leasing transactions and the application of uniform methods across all leases. Respondents were asked the extent of their agreement with these general normative principles and their views are summarized in Table 2. Row 1 deals with the general principle that there should be one accounting method for all leasing transaction. This is amplified to confirm that the method should apply to land and buildings and to intangible assets (rows 2-3). The final two rows focus on whether a de minimis threshold should apply to leases or whether the general concept of materiality is sufficient. 
[Table 2 about here]

The user group was in favor of all of these general principles. However, the preparer group was far less positive, on average and exhibited high variability. There was relatively moderate agreement, on average, with just two of the principles (rows 1 and 4). Thus, while recognizing the deficiencies of SSAP 21, preparers were not particularly supportive of the general principles of reform. This could stem from opposition to the G4+1 proposals per se, or aversion to any form of change, a manifestation of the status quo bias (Samuelson and Zeckhauser, 1988). Moreover, opposition to the G4+1 proposals could arise either from opposition to the conceptual basis of the principles or from expected adverse economic consequences for their companies should the new proposals form the basis of a new lease accounting standard.

There was only one significant difference associated with background characteristics. Preparers in companies with low lease usage favored the application of a single method to all tangible assets, including land and buildings (mean $=3.44)$, whereas those in companies with high operating lease usage opposed this (mean $=2.68$ ). Perhaps preparers with few property leases are more concerned with administrative simplicity than balance sheet impact (and vice versa for those with high exposure to property leases).

\subsection{Lease accounting proposals: specific issues}

While high quality accounting standards should preferably be based on concepts rather than arbitrary rules, supplementary rules are usually necessary to limit alternatives and ensure consistency of application. The G4+1 discussion paper considers and recommends ways of dealing with some of the complexities of lease contracts, specifically the treatment of renewal options, contingent rentals and rentals that vary in line with prices.

\subsubsection{Renewal options}

There are two main differences between SSAP 21 and the G4+1 proposals. Under SSAP 21, a renewal option (if reasonably likely to be exercised) is included in determining the lease term for classifying agreements as finance or operating leases. For a finance lease in which the exercise of a renewal option is reasonably certain, the present value of lease rentals payable in the initial period and the renewal period would generally appear on the balance sheet. While the G4+1 proposals would require the present value of all material 
lease agreements to be recorded on the balance sheet, they suggest that renewal options should not be anticipated. ${ }^{15}$ Thus only the present value of rentals payable in the initial period would appear on the balance sheet and hence shorter guaranteed terms could actually reduce balance sheet obligations for leases that are currently classified as finance leases.

Second, SSAP 21 makes no distinction between the renewal option and the value of the right to use the asset, whereas the G4+1 document proposes that the two should be recorded separately on the balance sheet, to highlight the flexibility of different lease agreement arrangements. It is proposed that option values could be ascertained through direct comparison with similar lease agreements without options.

Table 3, panel A provides a summary of responses concerning renewal options. Both groups are neutral regarding the benchmark SSAP 21 treatment (row 1). Preparers' views regarding the new proposals are both stronger and significantly different from those of users, with preparers agreeing that renewal options should not be anticipated but disagreeing that options should be recorded separately. The latter view may arise from the perceived difficulties of valuing the option. Preparers do not think that option values can be established by comparison with similar agreements; users are neutral. However, both groups envisage significant compliance costs (especially preparers) and the negotiation of shorter initial lease terms. The technical complexity of the treatment of renewal options may be contributing to the general neutrality (uncertainty) of the user group.

There were two significant differences relating to background characteristics. First, although both the high and low operating lease usage sub-groups agreed that the exercise of renewal options should not be anticipated, high users were in stronger agreement (mean $=3.91$ (high); 3.49 (low); row 2). Second, while preparers were neutral, on average, to the recording of renewal option assets and liabilities at the start of the lease, small company preparers were against the suggestion $($ mean $=2.54($ small $)$; mean $=3.05$ (large); row 1$)$.

[Table 3 about here]

\subsubsection{Contingent rentals}

Under SSAP 21, lease rentals contingent on asset usage or lessee revenues/profits are not included in the minimum lease payments used for lease classification, nor are they 
included in the capitalized value of finance leases recorded in the balance sheet. Similarly, under the G4+1 proposals, contingent rentals based on asset usage would not generally be anticipated but would be charged as an expense when the contingency arises. An exception to this general rule would be when the minimum lease payments are unrepresentative of the value of property rights conveyed, in which case a greater amount reflecting the value of such rights would be recognized. It is expected that this exception would be the norm in the case of contingent rentals based on lessee revenues or profits (para. 4.67). The proposals suggest that the value of property rights conveyed by a lease agreement with contingent rentals might be determined by comparison with lease payments for a similar agreement without contingent rentals. Respondents' views are shown in Table 3, panel B.

Only preparers agreed with the G4+1 proposal that contingent rentals generally should not be recognized on the balance sheet (row 1), and disagreed with the opposing view that estimated contingent rentals should be recorded on the balance sheet (row 2). Users were neutral to both options, on average, although there was wide dispersion in views. Both groups were neutral to the 'unrepresentativeness' exception to the non-recognition rule (row 3). This may reflect the difficulty associated with estimation of fair value, as preparers in particular did not believe that the G4+1 method of comparison with noncontingent agreements is valid (rows 4 and 5). These results suggest that the difficulties associated with estimating the value of future contingent rentals contribute to the view that contingent rentals should not be recognized on balance sheet. There were no significant differences relating to background characteristics.

4.5.3 Rentals that vary in line with prices (e.g., upwards-only rent reviews on leased land and buildings)

$70 \%$ of property (real estate) leases in the UK granted in 2002-03 contain a five-yearly review (BPF IPD, 2003). Under SSAP 21, any associated variation in lease rentals is not anticipated at the beginning of the lease term, but treated as an increase/decrease in liability in the period in which the price change occurs. The G4+1 consensus is that the likely future price changes should be estimated at the start of the lease contract and incorporated in the calculation of the present value of minimum lease payments, to ensure that the difference in values for lease agreements with and without rent reviews is not 
misleading. However, the ASB dissented from this view on the grounds that estimates of future price increases would be unreliable. Respondents' views are shown in Table 3, panel C.

Users' views were widely dispersed though, on average, neutral. Preparers agreed with the SSAP 21 treatment (row 1) and disagreed with the alternative G4+1 proposal (row 2). The perceived unreliability of estimating future price rises seems to be a major reason for this view (row 3).

In relation to background characteristics, familiarity had a significant impact on views, with those who best appreciate the issue (i.e. respondents 'familiar' with lease accounting) having stronger views. In particular, 'familiar' users disagreed with recognition based only on rentals at the beginning of the lease whereas 'less familiar' users agreed ('familiar' group mean $=2.50$; 'less familiar' group mean $=3.40$; row 1). Thus, the views of 'familiar' users were diametrically opposed to the views of all preparers (preparer mean $=$ 3.71). In addition, 'familiar' preparers strongly disagreed with recognizing rental estimates ('familiar' group mean $=2.36$; 'less familiar' group mean $=2.83$; row 2). This differentiates the views of this preparer sub-group even more from the views of all users (user mean $=3.00)$.

\subsection{Economic consequences}

Potential economic consequences were identified from the G4+1 discussion paper (ASB, 1999), from published responses to this (Finance \& Leasing Association, 1999) and from prior research (Taylor and Turley, 1985; Beattie et al., 1998). Respondents' views were elicited using two multi-part questions, the first covering all leased assets and the second focusing specifically on land and buildings (to deal with some consequences that are specific to land and buildings).

\subsubsection{Consequences of adopting the lease accounting proposals: all assets}

Respondent's views are shown in Table 4, panel A, in descending order of user group agreement.

[Table 4 about here] 
Not surprisingly, both respondent groups fully recognized that many operating leases would give rise to assets and liabilities on the balance sheet (row 1) and that this would lead to an increase in reported measures of gearing (row 2), consistent with prior empirical research (Beattie et al., 1998). ${ }^{16}$ Both groups also agreed that companies may need to renegotiate borrowing covenants although preparers' level of agreement was significantly stronger than that of users (row 6). Technical violation of accounting-based debt covenants is costly. Beneish and Press (1993) estimate that the average costs range between $1.2 \%$ and $2 \%$ of equity market value, or between $4.4 \%$ and $7.3 \%$ of the outstanding balances of the violated debt agreements. There were also similar levels of agreement by both groups that credit rating would fall for some companies (row 8).

Certain consequences impact primarily on lessees/lessors. Both groups agreed that lease terms would shorten to minimize lessees' balance sheet obligations (row 9). This suggests a transfer of risk to lessors from lessees, so would be of some benefit to lessee companies. However only preparers thought that lease finance would be less attractive (row 11), although they were neutral about whether this would affect UK investment and leasing volumes (row 16), and disagreed that new assets would be purchased (or constructed) rather than leased (row 14). By contrast, users disagreed that investment and leasing volumes would be affected and were neutral the impact on purchase decisions. This might suggest that, although less attractive, lease finance would still compare favorably with alternative sources of finance. Alternatively, it might suggest that companies don't always have the choice between purchase/construction and leasing. The use of specific assets may only be available in one form or the other. General comments made by the respondents provide some indication of this being the case (for example, "the alternative to leasing isn't always available" and "the properties we operate from are only available on lease").

Users agreed significantly more strongly than preparers that users' assessments of companies would be improved (rows 3 and 4) if the proposals were adopted. This is somewhat inconsistent with preparers' rejection that the current accounting standard impairs users' assessments (Table 1). Users agreed that they would increase risk estimates, though they were neutral that the assessment of either debt-paying ability or dividendpaying ability would be affected (rows 5, 13 and 15). Preparers were neutral to the first two consequences, but did think that dividend-paying ability would be adversely affected. 
Users were neutral regarding the effect on administrative burdens and compliance costs, whereas preparers agreed that these would increase significantly (rows 10 and 11). Finally, users agreed that the proposals would reflect the financial flexibility of different leasing arrangements, while preparers disagreed (row 7).

This set of responses highlights the fact that it is the economic consequences relating to company risk (and the perception of it) that are of prime importance in the debate on lease accounting reform. The increase in measured levels of gearing would affect debt covenants, lease terms, credit ratings, financing choices and users' assessment of company risk.

\subsubsection{Consequences of adopting the lease accounting proposals: land and buildings}

The proposed new approach to lease accounting would have a major impact on property leases (i.e., land and buildings). Under SSAP 21, such leases are generally treated as offbalance sheet operating leases, since the landlord lessor retains a significant residual interest in the property. Under the G4+1 proposals, the present value of future rentals and an estimate of future increases would be recorded on the lessee's balance sheet. The views of respondents on various potential consequences of the new proposals being applied to the leasing of land and buildings are shown in Table 4, panel B, in descending order of user group agreement. The question in row 7 is reiterated in the specific context of land and buildings; the other potential consequences are peculiar to land and buildings.

The new proposals suggest that balance sheet recognition of the rights and obligations to occupy leased property would enable any loss on leased property to be written off when it occurs rather than on vacation of the property, and any increase in value arising from subleasing at a higher rent to be shown. Both groups of respondents appear to support these arguments (rows 1 and 2). Consistent with the general trends observed in Table 4, panel A, the difficulty and costs involved in estimating the present value of future property rent increases (row 3) were not recognized by users, but were strongly identified by preparers. The G4+1 discussion paper suggests that an estimate of the fair value of a property lease subject to rent reviews might be obtained by comparison with a similar property lease that was not subject to rent reviews. However, according to the Finance and Leasing 
Association (FLA) in their response to the new proposals, virtually no such leases exist in the UK. Preparers recognized that the combined profit and loss expense of depreciation and interest would exceed market rent in the early years of the lease agreement (row 4); perhaps surprisingly, users did not appreciate this fact.

The FLA suggests that rent yields may rise to reflect an increase in lessors' risk and that it may be difficult to fund new property development without the security of long-term tenants. On average, both groups were neutral to these possible property market consequences (rows 5 and 6); their views on rent yields are surprising and may not be shared by landlords. The purchase of property instead of leasing was considered unlikely by both groups (row 7), the views being stronger than in the case of assets generally (Table 4, panel A). Perhaps the choice to purchase specific properties is not an option, as they are already owned by institutions or property companies who wish to retain them for renting to tenants.

\subsubsection{Background characteristics}

The impact on respondent views of three background characteristics (familiarity with the G4+1 proposals, level of company lease usage and company size) was examined. Seven significant differences existed. (In considering these, it should be borne in mind that, when conducting multiple individual tests, some random differences are likely to emerge as statistically significant.) First, although users were neutral overall to the view that companies would find it difficult and expensive to estimate the present value of future property rent increases, 'familiar' users disagreed ('familiar' group mean $=2.54$; 'less familiar' group mean $=3.28$; panel B, row 3). The level of operating lease usage gave rise to two differences: the view that leasing will become less attractive was driven by low lease usage preparers (mean $=3.18$ (high); mean $=3.57$ (low); panel A, row 12), whereas disagreement with the view that companies would buy rather than lease property was driven by high lease usage preparers (mean $=2.58$ (high); mean $=2.97$ (low); panel $\mathrm{B}$, row 7). There are two possible, non-mutually exclusive, explanations for these different opinions. First, high lease usage companies may believe that they have chosen lease finance for sound commercial reasons that will not be greatly affected by the change in accounting treatment. Nevertheless, they would still prefer to keep their leased assets, particularly land and buildings, off-balance sheet. Second, high lease usage companies 
may perceive that they are in a stronger bargaining position with lessors, compared to low lease usage companies. Thus, they may expect to be able to negotiate relatively more favorable terms (such as shorter leases with renewal options or break clauses) in response to any new accounting requirements. In other words, they expect leasing to continue to be an attractive form of finance but would like flexibility within any new accounting standard to enable them to minimize the impact on their financial statements.

The remaining four significant differences concerned company size. Large companies were more acutely aware than those in small companies of the need to renegotiate bond covenants $($ mean $=4.13$ (large); 3.79 (small); panel A, row 6), perhaps because large companies are likely to have greater exposure to securitized long-term debt (Lasfer and Levis, 1998; Bevan and Danbolt, 2002). On the other hand, small companies showed greater concern over the expected increase in administrative burdens (mean $=3.83$ (small); 3.42 (large); panel A, row 10) and compliance costs (mean = 3.86 (small); 3.51 (large); Table 4, panel A, row 11). Presumably, small companies have a smaller administrative team over which to spread such matters.

Further, large companies agreed more strongly that lease terms would shorten (mean = 3.62 (large); mean $=3.15($ small $)$; panel A, row 9), presumably reflecting the relative bargaining power that large firms have in contract negotiations. Finally, large companies tended to agree that 'companies would be reluctant to enter long property leases making it difficult to fund new property development' in contrast to small companies who disagreed $($ mean $=3.37$ (large); mean $=2.77$ (small); panel $\mathrm{B}$, row 8). This may reflect large company views on the first, rather than the second, part of the statement. There is anecdotal evidence that companies may wish to negotiate shorter lease contracts for commercial rather than accounting reasons. Large companies may find this easier to accomplish than small companies in view of their stronger negotiating position.

\subsection{Lease accounting alternatives}

The UK Finance \& Leasing Association suggested an 'improved' version of SSAP 21 in which the arbitrary $90 \%$ classification test for finance leases of SSAP 21 would be reduced to $75 \%$. They argue that this would bring the vast majority of UK operating leases onto the balance sheet while retaining the existing principles that are widely understood. The 
SSAP 21 and G4+1 treatments are also included to serve as benchmarks. We also asked about increased footnote disclosure and full capitalization without any additional disclosure. Responses are shown in Table 5, panel A, in descending order of user agreement.

[Table 5 about here]

Users agreed with the G4+1 treatment, disagreed with the SSAP 21 treatment and were neutral to changing the classification threshold (rows 2-4). Both groups agreed that lease commitments should be analyzed by asset type, as already practiced in the UK, but not in all countries (row 1). On the other hand, both groups disagreed with the suggestion that capitalization made additional disclosure unnecessary (row 5). Although users were neutral overall to the $75 \%$ threshold alternative, 'familiar' users disagreed ('familiar' group mean $=2.50$; 'less familiar' group mean $=3.13$; panel A, row 2).

\subsection{Implementation of the lease accounting proposals}

Respondents were asked their opinion on four alternatives for implementing the new proposals - immediate implementation for all leases and three different transition arrangements. Responses are summarized in Table 5, panel B.

Users favored immediate implementation to new and existing leases (row 1) perhaps to minimize the disruption and uncertainty associated with multiple change points and also to benefit immediately from the improved information. They disagreed with the suggestion of a transition period in which operating lease capitalization would be required for new leases only (row 4) and were neutral about disclosure of capitalized values. Preparers disagreed with all four alternatives, although this may simply reflect their disagreement with the general principles of the proposals. Preparers' views varied highly, however. There were no significant differences relating to background characteristics.

\section{Summary and conclusions}

This paper reports the findings from a questionnaire survey of UK users and preparers regarding lease accounting reform. In common with all research methods, the survey method used in the present study suffers from a number of limitations that must be borne in mind when evaluating the results. There are three principal potential limitations: (i) non-response bias, which can mean that the findings are not generalizable to the population 
of interest; (ii) uninformed respondent bias, which means that the respondent does not possess the appropriate knowledge or experience to answer the questions posed; and (iii) the risk that respondents do not answer with complete honestly. A further limitation of the study is that, as respondents were confined to UK subjects, the results cannot be generalized beyond the UK, especially where there are significant institutional differences. One might speculate, for example, that the views of users in less active capital markets to that in the UK (and US) would differ less from those of preparers. The extent of variation in the views of users and preparers across countries is also of interest. ${ }^{17}$ Further research conducted in other jurisdictions could usefully be undertaken to investigate these issues.

This survey has shown that the current UK lease accounting standard, which is representative of many extant lease standards worldwide in key respects, is recognized as deficient in a number of respects by both users and preparers, thereby failing to meet the criteria for a high quality accounting standard. In particular, they agreed that it allows transactions to be deliberately structured for classification as off-balance sheet operating leases, thereby enabling similar transactions to be accounted for in different ways. However, preparers did not believe that this impaired various user decisions.

Expert users were strongly in favor of the general principles in the G4+1 proposals. However, preparers were far less positive, showing only moderate support for just two of the principles (that all material leases should be recognized on the lessee's balance sheet and that one accounting method should apply to all lease transactions). The G4+1 discussion paper makes specific proposals for the treatment of renewal options, contingent rentals and rentals that vary in line with prices. While the views of users were generally neutral, preparers were against the proposals, instead favoring the treatment of these issues in the current standard. The main arguments against the detailed proposals seemed to be based on cost-benefit considerations and concerns about their operationality. Given that the preparers (companies) initially bear the costs and users (analysts and others) are more likely to reap the direct benefits from improved financial information, the differing responses from preparers and users are understandable. The attitude of preparers is entirely consistent with the arguments put forward by Parfet (2000) who suggests that accounting standards 'are overhead, not something a customer consumes and will pay for' (p. 483). Consequently, business responds toward new accounting rules with a 'healthy 
negative bias', which is 'one of the healthy checks and balances in the great standard setting system we have' (p. 483; p. 484). However, preparers' expressed views may ignore any potential, indirect, long-term benefits that companies may enjoy from improved user/market confidence as a result of the improved information (e.g., reduced costs of finance). Accounting standard setters act as arbiter between those who might benefit from the improved information and those who will incur the costs of providing the information.

Another challenge faced by accounting standard setters is to identify the economic consequences that may result from a change in accounting standards, estimate their magnitude and then take them into account. The current paper contributes by asking key interested parties what they believe will be the consequences if the G4+1 proposals are adopted. There was clear acceptance by both users and preparers that additional assets and liabilities would be brought on to the balance sheet under the new proposals and that this would impact on reported gearing. This was considered likely to lead to: re-negotiation of borrowing covenants; a reduction in credit ratings for some companies; improved users' evaluation of long-term financial commitments; and improved company comparisons. Additional compliance costs and administrative burdens relating to lease accounting were anticipated by preparers (particularly from smaller companies), but not by users.

Both groups believed that lease terms would become shorter to minimize balance sheet obligations and some preparers (from low operating lease usage companies), but not users, also believed that the proposals would make lease finance less attractive. However, neither group believed that the proposals would adversely affect UK investment and leasing volumes in the short-term, nor that they would substantially change the UK property market. In particular, the purchase of property rather than leasing was considered unlikely, probably because the purchase alternative is not always available. Overall, respondents anticipated significant economic consequences if the proposals are incorporated in a new lease accounting standard.

Alternatives to the new proposals were explored but none appeared to be favored by preparers. They were neutral to the current SSAP 21 treatment and to disclosure (rather than recognition) approaches, while opposing a 75\% threshold for finance leases, and the suggestion of capitalization in the balance sheet without footnote disclosure of other 
material aspects. By contrast, users clearly favored the G4+1 proposals. Immediate implementation of the new proposals to new and existing leases was favored by the user group, implying that a 'clean break' would be preferred over a transition period. Preparers disagreed with all four of the alternative suggestions for implementation, probably reflecting general disagreement with the new proposals per se.

The findings of the present study demonstrate very clearly that the views of expert users and preparers differ significantly. This suggests that the interests of these two groups' conflict and standard-setters must address this. These group differences also show that concerns about the general under-representation of users' views on accounting standards are well-founded. By examining the views of representatives from both key constituencies (users and preparers), investigating the impact of background characteristics on those views, and covering a range of key reform issues (e.g. general principles, economic consequences, implementation), the ex ante evidence presented here provides a more balanced and comprehensive set of views in support of the standard setting process than has hitherto been available.

The findings also provide further evidence that lease accounting standards currently in force worldwide are not perceived as being of high quality. It is shown that the distinction between operating and finance leases is not generally believed to be a useful principle on which to base a standard. The distinction is not clear-cut and hence the detailed accounting rules that emerge are inherently unsatisfactory. The principle upon which there is widespread agreement is that all material rights and obligations arising from lease contracts should be recognized on the balance sheet. It is the detailed implementation guidance associated with this principle that is the subject of most debate. Further research to explore the detailed nature of lease contracts across different jurisdictions and investigate the economic consequences of adopting different detailed implementation guidance would further assist in the process of lease accounting reform. Ultimately, however, it will be the responsibility of the standard setters to balance conceptual principles and economic consequences and also to resolve the conflicts of interest that exist between the key interested parties (Cyert and Ijiri, 1974). 


\section{Notes}

${ }^{1}$ This relates to 2002/03 year-ends. Mean figures are even higher: 0.70 and 95.3 , respectively.

2 The G4+1 group of standard-setters (now a defunct body) comprised the standard-setting bodies of Australia, Canada, New Zealand, the UK and the US, as well as the IASC.

${ }^{3}$ Under SFAS 13, the total minimum future operating lease rentals are shown separately for each of the first five years and combined thereafter. Under SSAP 21, it is only the next year's (rather than total) minimum future operating lease rentals that must be disclosed, analysed according to the period in which the annual commitment expires (less than one year, two to five years and more than five years). This is further analysed by asset category ('land and buildings' and 'other assets').

${ }^{4}$ Further, there is evidence that at least some investment analysts and credit rating agencies recast financial statements by calculating the assets and liabilities implicit in off-balance sheet operating leases (e.g., Dresdner Kleinwort Benson, 1998).

${ }^{5}$ A similar response was reported by Drury and Braund (1990) in their (post-SSAP 21) general survey of the leasing decision.

${ }^{6}$ Each questionnaire contained an identifying number to allow non-respondents to be followed up; thus the responses were confidential but not anonymous.

${ }^{7}$ Respondents were asked to self-assess their level of familiarity with the new lease accounting proposals by selecting one of four categories. The categories 'very familiar' and 'moderately familiar' were subsequently combined to form the 'familiar' sub-group, while the categories 'slightly familiar' and 'not at all familiar' were combined to form the 'less- familiar' sub-group.

${ }^{8}$ Data for these additional tests were all extracted from Datastream.

${ }^{9}$ Selected key findings are summarised in a practitioner-oriented report published by the ICAEW that overviews a range of studies in the area of leasing (Beattie et al., 2004).

${ }^{10}$ A questionnaire investigating 'leasing and corporate financing decisions' was sent out over a similar time period to the remaining two-thirds of the UKQI (UK quoted industrials) population. Respondents to this survey were invited to request the 'lease accounting reform' questionnaire and 13 requested and completed the questionnaire.

${ }^{11}$ Including 136 negative responses from the investment analysts, the overall response rate was $38 \%$. Interestingly, the major reasons for negative response were insufficient knowledge of lease accounting (47\%) and lack of time/too busy (40\%).

${ }^{12}$ These tests suffer from a number of well-known limitations; see Wallace and Mellor (1988) and Wallace and Cooke (1990) for discussions.

${ }^{13}$ Responses were classified into three approximately equal sized groups (early, middle and late), according to the date that their completed questionnaire was received.

14 Opinion varies regarding whether it is better to use parametric or non-parametric statistical tests on responses from Likert-type scales. Strictly, a Likert scale is not an interval scale and so the more conservative non-parametric tests should be used. In practice, however, the results of both forms of test are very similar and so the more familiar and tractable parametric versions are commonly used. Studies involving Likert scales that use parametric tests include Bebbington et al. (1994), Yap (1997) and Hermanson (2000), while Deegan and Rankin (1999) use non-parametric tests exclusively. 
${ }^{15}$ The use of 'break clauses' is more common in the UK commercial property market than 'renewal options' but the effect is very similar. These break clauses can be used to give the lessee an option to exit the lease contract at various stages during the contract (e.g., every five years). It is, in effect, an option to 'not renew'.

${ }^{16}$ These consequences have likely indirect economic consequences because of the impact on matters such as breach of debt covenants, which affect cash flows.

${ }^{17}$ We are grateful to an anonymous reviewer for suggesting these points to us. 


\section{References}

Abdel-khalik, A.R., (1981). The Economic Effects on Lessees of FASB Statement No. 13, Accounting for Leases. Stamford, CT: Financial Accounting Standards Board.

ASB (1999). Leases: Implementation of a New Approach, Discussion Paper. London: Accounting Standards Board.

ASB (2004). http://www.asb.org.uk/asb/technical/projects/project0025.html London: Accounting Standards Board.

ASC (1984). Accounting for Leases and Hire Purchase Contracts, Statement of Standard Accounting Practice No. 21. London: Accounting Standards Committee.

Ashton, R.K. (1985). Accounting for finance leases: a field test. Accounting and Business Research, 15(59), 233-238.

Beattie, V. and Pratt, K. (2002). Voluntary Annual Report Disclosures: What Users Want. Edinburgh: Institute of Chartered Accountants of Scotland.

Beattie, V. and Pratt, K. (2003). Issues concerning web-based business reporting: an analysis of the views of interested parties. British Accounting Review, 35(2), 155-187.

Beattie, V.A., Edwards, K. and Goodacre, A. (1998). The impact of constructive operating lease capitalisation on key accounting ratios. Accounting and Business Research, 28(4), 233254.

Beattie, V.A., Goodacre, A. and Thomson, S. (2000). Recognition versus disclosure: an investigation of the impact on equity risk using UK operating lease disclosures. Journal of Business Finance \& Accounting, 27(9\&10), 1185-1224.

Beattie, V.A., Goodacre, A. and Thomson, S. (2004). Leasing: Its Financing Role and Accounting Treatment. London: Institute of Chartered Accountants in England and Wales.

Bebbington, J., Gray, R., Thomson, I. and Walters, D. (1994). Accountants' attitudes and environmentally-sensitive accounting. Accounting and Business Research, 24(94), 109120.

Beneish, M.D. and Press, E. (1993). Costs of technical violation of accounting-based debt covenants. Accounting Review, 68(2), 233-257.

Bevan, A.A. and Danbolt, J. (2002). Capital structure and its determinants in the UK. Applied Financial Economics, 12(3), 159-170.

Blake, J., Salas, O.A. and Clarke, J. (1995). Managing the economic impact of accounting regulation: the Spanish case. European Business Review, 95(6), 26-34.

Bowman, R.G. (1980). The debt equivalence of leases: an empirical investigation. Accounting Review, 55(2), 237-253.

BPF IPD (2003). Annual Lease Review. British Property Federation.

Breton, G. and Taffler, R.J. (1995). Creative accounting and investment analyst response. Accounting and Business Research, 25(98), 81-92.

CA Magazine (1999). Who's who in fund management 1999, December, pp. 31-70.

Collins, D.L., Pasewark, W.R. and Strawser, J.R. (2002). Characteristics influencing perceptions of accounting pronouncement quality. Accounting Horizons, 16(2), 137-151. 
Collins, W., Davie, E., and Weetman, P. (1996). Lobbying on accounting issues: preparer/user imbalance in the case of the operating and financial review. Accounting, Auditing and Accountability Journal, 9(1), 59-76.

Cyert, R.M. and Ijiri, Y. (1974). Problems of implementing the Trueblood objectives report. Journal of Accounting Research Supplement, 29-45.

Deegan, C. and Rankin, M. (1999). The environmental expectations gap: Australian evidence. British Accounting Review, 31(3), 313-346.

Dresdner Kleinwort Benson (1998). Operating Leases: The Retail House of Cards. London: Dresdner Kleinwort Benson Research.

Drury, C. and Braund, S. (1990). The leasing decision: a comparison of theory and practice. Accounting and Business Research, 20(79), 179-191.

Dunne, T., Helliar, C., Mallin, C., Moir, L., Ow-Yong, K. and Power, D. (2003). The Financial Reporting of Derivatives and Other Financial Instruments: A Study of the Implementation and Disclosures of FRS 13. London: Institute of Chartered Accountants in England and Wales.

El-Gazzar, S.M. (1993). Stock market effects of the closeness to debt covenant restrictions resulting from capitalization of leases. Accounting Review, 68(2), 258-272.

Ely, K.M. (1995). Operating lease accounting and the market's assessment of equity risk. Journal of Accounting Research, 33(2), 397-415.

FASB (1976). Accounting for Leases, Statement of Financial Accounting Standards No.13. Stamford, CT: Financial Accounting Standards Board.

Finance \& Leasing Association (1999). Think again Sir David: Lease Accounting Reform is not as Simple as you Think. Press Release, 17 December, London: Finance \& Leasing Association.

Finnerty, J.E., Fitzsimmons, R.N. and Oliver, T.W. (1980). Lease capitalization and systematic risk. Accounting Review, 55(4), 631-639.

Garrod, N. (1989). Regulation and response: the case of lease disclosure in the UK. Research in Accounting Regulation, 3, 69-92.

Georgiou, G. (2004). Corporate lobbying on accounting standards: methods, timing and perceived effectiveness. Abacus, 40(2), 219-237.

Godfrey, J.M. and Warren. S.M. (1995). Lessee reactions to regulation of accounting for leases. Abacus, 31(2), 201-228.

Goodacre, A. (2003). Operating lease finance in the UK retail sector. International Review of Retail, Distribution and Consumer Research, 13(1), 99-125.

Gopalakrishnan, V. and Parkash, M. (1996). The debt-equivalency of recognized vs. disclosed obligations: an examination of borrower and lender perceptions. Research in Accounting Regulation, 10, 63-77.

Hartman, B.P. and Sami, H. (1989). The impact of the accounting treatment of leasing contracts on user decision making: a field experiment. Advances in Accounting, 7, 23-35.

Hermanson, H.M. (2000). An analysis of the demand for reporting on internal control. Accounting Horizons, 14(3), 325-341. 
Herz, R.H. (2003). A year of challenge and change for the FASB. Accounting Horizons, 17(3), 247255.

Holthausen, R.W. and Leftwich, R.W. (1983). The economic consequences of accounting choice: implications of costly contracting and monitoring. Journal of Accounting and Economics, 5(2), 77-117.

Hooks, J. and van Staden, C. (2004). Preparers' perceptions of the decision usefulness of FRS15. Qualitative Research in Accounting and Management, 1(1), 46-65.

IASB (2003). Leases, IAS 17. London: International Accounting Standards Board.

IASB (2005). http://www.iasb.org/current/research_topics.asp London: International Accounting Standards Board.

Imhoff, E.A. (1998). Six commentaries on characteristics of high quality accounting standards. Accounting Horizons, 12(2), 160-191.

Imhoff, E.A. and Thomas, J.K. (1988). Economic consequences of accounting standards: the lease disclosure rule change. Journal of Accounting and Economics, 10(4), 277-310.

Imhoff, E.A., Lipe, R.C. and Wright, D.W. (1991). Operating leases: impact of constructive capitalization. Accounting Horizons, 5(1), 51-63.

Imhoff, E.A., Lipe, R.C. and Wright, D.W. (1993). The effects of recognition versus disclosure on shareholder risk and executive compensation. Journal of Accounting, Auditing and Finance, 8(4), 335-368.

Imhoff, E.A., Lipe, R.C. and Wright, D.W. (1997). Operating leases: income effects of constructive capitalization. Accounting Horizons, 11(2), 12-32.

Jonas, G.J. and Young, S.J. (1998). Bridging the gap. Who can bring a user focus to business reporting? Accounting Horizons, 12(2), 154-159.

Joshi, P.L. and Ramadhan, S. (2002). The adoption of international accounting standards by small and closely held companies: evidence from Bahrain. International Journal of Accounting, 37(4), 429-440.

La Porta, R., Lopez-de-Silanes, F., Shleifer, A. and Vishny, R.W. (1997). Legal determinants of external finance. Journal of Finance, 52(3), 1131-50.

La Porta, R., Lopez-de-Silanes, F., Shleifer, A. and Vishny, R.W. (1998). Law and finance. Journal of Political Economy, 106(6), 1113-55.

Lasfer, M.A. and Levis, M. (1998). The determinants of the leasing decision of small and large companies. European Financial Management, 4(2), 159-184

Levitt, A. (1998). The impact of high quality accounting standards. Accounting Horizons, 12(1), 7982.

McBarnet, D. and Whelan, C. (1991). The elusive spirit of the law: formalism and the struggle for legal control. Modern Law Review, 54(6), 848-873.

McBarnet, D. and Whelan, C. (1992). Regulating accounting: limits in the law, Chapter 7, 99-111. In Bromwich, M. and Hopwood, A. (Eds.), Accounting and the Law. London: Prentice Hall.

McBarnet, D. and Whelan, C. (1999). Creative Accounting and the Cross-Eyed Javelin Thrower. Chichester: John Wiley \& Sons. 
McGregor, W. (1996). Accounting for Leases: A New Approach. Stamford CT: Financial Accounting Standards Board.

Munter, P. and Ratcliffe, T.A. (1983). An assessment of user reactions to lease accounting disclosure. Journal of Accounting, Auditing and Finance, 6(2), 108-114.

Nelson, A.J. (1963). Capitalizing leases - the effect on financial ratios. Journal of Accountancy, July, 49-58.

Nixon, B. (1997). The accounting treatment of research and development expenditure: views of UK company accountants. European Accounting Review, 6(2), 265-277.

Oppenheim, A.N. (1966). Questionnaire Design and Attitude Measurement. Heinemann.

Parfet, W.U. (2000). Accounting subjectivity and earnings management: a preparer perspective. Accounting Horizons, 14(4), 481-488.

Prakash, P. and Rappaport, A. (1977). Information inductance and its significance for accounting. Accounting, Organizations and Society, 2(1), 29-38.

Rajan, R.G., and Zingales, L. (1995). What do we know about capital structure choice? Some evidence from international data. Journal of Finance, 50(5), 1421-60.

Reither, C.L. (1998). What are the best and the worst accounting standards? Accounting Horizons, 12(3), 283-292.

Ro, B.T. (1978). The disclosure of capitalized lease information and stock prices. Journal of Accounting Research, 16(2), 315-340.

Samuelson, W. and Zeckhauser, R. (1988). Status quo bias in decision making. Journal of Risk and Uncertainty, 1(1), 7-59.

Schipper, K. (1994). Academic accounting research and the standard setting process. Accounting Horizons, 8(4), 61-73.

Schipper, K. (2005). The introduction of International Accounting Standards in Europe: Implications for international convergence. European Accounting Review, 14(1), 101-126.

Taylor, P. and Turley, S. (1985). The views of management on accounting for leases. Accounting and Business Research, 16(61), 59-67.

Wallace, R.S.O. and Cooke, T.E. (1990). Nonresponse bias in mail accounting surveys: a pedagogical extension. British Accounting Review, 22(3), 283-288.

Wallace, R.S.O. and Mellor, C.J. (1988). Nonresponse bias in mail accounting surveys: a pedagogical note. British Accounting Review, 20(2), 131-139.

Wilkins, T. (1984). A behavioural investigation of alternative methods of financing capital acquisitions and lease capitalisation. Accounting and Business Research, 14(56), 359-366.

Wilkins, T. and Zimmer, I. (1983a). The effect of leasing and different methods of accounting for leases on credit evaluations. Accounting Review, 58(4), 749-764.

Wilkins, T. and Zimmer, I. (1983b). The effect of alternative methods of accounting for leases - an experimental study. Abacus, 19(1), 64-75.

Yap, C. (1997). Users' perceptions of the need for cash flow statements - Australian evidence. European Accounting Review, 6(4), 653-672. 


\section{Table 1: Views on accounting standards generally and suggested deficiencies in extant leasing standards}

Panel A: Accounting standards generally

\begin{tabular}{|c|c|c|c|c|c|c|}
\hline & \multirow[b]{2}{*}{ Question asked (abbreviated) $^{1 \mathrm{a}}$} & \multicolumn{4}{|c|}{$\begin{array}{c}\text { Mean } \\
\text { (std. dev.) }\end{array}$} & \multirow[b]{2}{*}{ Diff ${ }^{5}$} \\
\hline & & Users & Preparers & Users & Preparers & \\
\hline 1. & $\begin{array}{l}\text { Accounting standards are: } \\
\text { an undesirable and unnecessary intrusion into company } \\
\text { activities }\end{array}$ & 32 & 80 & $\begin{array}{c}1.34 * * * \\
(0.83)\end{array}$ & $\begin{array}{c}1.51^{* * * *} \\
(0.80)\end{array}$ & $\mathrm{ns}$ \\
\hline 2. & $\begin{array}{l}\text { desirable and impose no significant burden on } \\
\text { companies }\end{array}$ & 35 & 82 & $\begin{array}{l}3.34 \\
(1.24)\end{array}$ & $\begin{array}{l}2.67 * * \\
(1.19)\end{array}$ & 0.01 \\
\hline 3. & $\begin{array}{l}\text { desirable but do impose a significant burden on } \\
\text { companies }\end{array}$ & 37 & 90 & $\begin{array}{c}3.27 \\
(1.15)\end{array}$ & $\begin{array}{c}3.73^{* * * *} \\
(1.10)\end{array}$ & 0.05 \\
\hline
\end{tabular}

Panel B: Suggested deficiencies in the current lease accounting standards

\begin{tabular}{|c|c|c|c|c|c|c|c|}
\hline \multirow[b]{3}{*}{1.} & \multirow[b]{2}{*}{$\begin{array}{l}\text { Question asked (abbreviated) } \\
\text { To what extent do you agree with the following } \\
\text { suggested deficiencies in SSAP } 21 \text { ? }\end{array}$} & \multicolumn{2}{|c|}{ No of responses ${ }^{4}$} & \multicolumn{2}{|c|}{$\begin{array}{c}\text { Mean } \\
\text { (std. dev.) }\end{array}$} & \multirow[t]{2}{*}{$\begin{array}{l}\text { Preparer } \\
\text { rank }^{1 \mathbf{b}}\end{array}$} & \multirow[b]{2}{*}{ Diff $^{5}$} \\
\hline & & Users & Preparers & Users & Preparers & & \\
\hline & $\begin{array}{l}\text { Permits leasing transactions to be deliberately } \\
\text { structure for classification as operating leases }\end{array}$ & 38 & 86 & $\begin{array}{c}4.16^{* * * *} \\
(0.72)\end{array}$ & $\begin{array}{c}4.12 * * * \\
(0.85)\end{array}$ & 1 & ns \\
\hline 2. & $\begin{array}{l}\text { Requires estimation of balance sheet impact of } \\
\text { operating leases based on limited information }\end{array}$ & 39 & 85 & $\begin{array}{c}4.13 * * * \\
(0.70)\end{array}$ & $\begin{array}{c}3.42 * * * \\
(0.85)\end{array}$ & 5 & 0.01 \\
\hline 3. & $\begin{array}{l}\text { Substantially similar leasing transactions can be } \\
\text { accounted for in different ways }\end{array}$ & 39 & 86 & $\begin{array}{c}4.08 * * * \\
(0.62)\end{array}$ & $\begin{array}{c}3.91 * * * \\
(0.82)\end{array}$ & 2 & ns \\
\hline 4. & $\begin{array}{l}\text { No balance sheet recognition of material operating } \\
\text { lease assets and liabilities }\end{array}$ & 40 & 87 & $\begin{array}{c}3.98 * * * \\
(0.89)\end{array}$ & $\begin{array}{c}3.81 * * * \\
(1.04)\end{array}$ & 3 & ns \\
\hline 5. & No single accounting method applicable to all leases & 40 & 87 & $\begin{array}{c}3.90 * * * \\
(1.01)\end{array}$ & $\begin{array}{l}3.61 * * * \\
(0.98)\end{array}$ & 4 & ns \\
\hline 6. & Impairs users' comparison between companies & 40 & 87 & $\begin{array}{c}3.73 * * * \\
(1.01)\end{array}$ & $\begin{array}{c}3.21 \\
(1.11)\end{array}$ & 8 & 0.05 \\
\hline 7. & $\begin{array}{l}\text { Impairs users' evaluation of lessees' financial } \\
\text { commitments }\end{array}$ & 39 & 87 & $\begin{array}{c}3.72 * * * \\
(0.97)\end{array}$ & $\begin{array}{c}3.07 \\
(1.05)\end{array}$ & 9 & 0.01 \\
\hline 8. & $\begin{array}{l}\text { Lease classification requires difficult and subjective } \\
\text { judgments }\end{array}$ & 40 & 87 & $\begin{array}{c}3.68 * * * \\
(0.86)\end{array}$ & $\begin{array}{l}3.28 * * * \\
(0.98)\end{array}$ & 6 & 0.05 \\
\hline 9. & $\begin{array}{l}\text { Inconsistency with substance over form principle FRS } \\
\text { 5) }\end{array}$ & 32 & 82 & $\begin{array}{c}3.53 * * * \\
(0.80)\end{array}$ & $\begin{array}{l}3.26 * * \\
(1.08)\end{array}$ & 7 & ns \\
\hline 10. & $\begin{array}{l}\text { Impairs users' estimation of risks involved in } \\
\text { providing finance to lessee companies }\end{array}$ & 37 & 84 & $\begin{array}{c}3.38 * * \\
(0.92)\end{array}$ & $\begin{array}{c}2.77 * * \\
(1.00)\end{array}$ & 10 & 0.01 \\
\hline
\end{tabular}

Notes

1. a. Table is presented using the logical question order appearing in the questionnaire

b. Table is ranked by mean response of users; Preparer rank $=$ rank of preparers' mean response

2. Response categories are: $1=$ strongly disagree, $2=$ disagree, $3=$ neutral, $4=$ agree, $5=$ strongly agree

3. Significance of t-test of whether mean response is significantly different from $3=$ neutral;

$* * *$ and $* *=$ significant at $1 \%$ and $5 \%$ levels, respectively (2-tail test)

4. Number of responses to each individual question excluding 'Don't know' responses

5. P-value from a Wilcoxon-Mann-Whitney test for significant difference between respondent group medians; significance levels of $5 \%$ and $1 \%$ are reported (2-tail test); ns = not significant. 


\section{Table 2: Views on the general principles in the G4+1 lease accounting proposals}

\section{Question asked (abbreviated) ${ }^{1 \mathrm{a}}$}

To what extent do you agree with the following principles in the proposed approach to lease accounting?

1. One accounting method should be applicable to all leasing transactions

2. A lease accounting method should apply to all types of tangible asset, including land and buildings

3. A lease accounting method should be equally applicable to leases of intangible and tangible assets

4. All material leases should give rise to an asset and liability on the lessee's balance sheet

5. A lease accounting method should not contain a threshold to exclude short leases; this should be addressed by the concept of materiality

\begin{tabular}{|c|c|c|c|c|}
\hline \multicolumn{2}{|c|}{ No of responses 4} & \multicolumn{2}{|c|}{$\begin{array}{c}\text { Mean }^{2,3} \\
\text { (std. dev.) }\end{array}$} & \multirow[b]{2}{*}{ Diff ${ }^{5}$} \\
\hline Users & Preparers & Users & Preparers & \\
\hline 39 & 89 & $\begin{array}{c}3.72 * * * \\
(1.07)\end{array}$ & $\begin{array}{l}3.32 * * \\
(1.25)\end{array}$ & ns \\
\hline 39 & 88 & $\begin{array}{c}3.74 * * * * \\
(1.02)\end{array}$ & $\begin{array}{c}3.07 \\
(1.27)\end{array}$ & 0.01 \\
\hline 39 & 86 & $\begin{array}{c}3.33 * * \\
(0.96)\end{array}$ & $\begin{array}{c}3.01 \\
(1.13)\end{array}$ & $\mathrm{ns}$ \\
\hline 40 & 89 & $\begin{array}{c}3.95 * * * \\
(0.81)\end{array}$ & $\begin{array}{c}3.27 * * \\
(1.23)\end{array}$ & 0.01 \\
\hline 36 & 88 & $\begin{array}{c}3.67 * * * \\
(0.86)\end{array}$ & $\begin{array}{c}2.96 \\
(1.15)\end{array}$ & 0.01 \\
\hline
\end{tabular}

Notes: See Table 1 


\section{Table 3: Views on the specific G4+1 proposals}

Question asked (abbreviated) ${ }^{1 \mathbf{a}}$

To what extent do you agree with the following?

1. Estimates of probable amounts paid under options should be recorded as an asset and liability at beginning of lease

2. Exercise of renewal options should not be anticipated

3. Renewal options of significant value should be recorded as a separate asset and liability

4. Renewal option value can be reliably ascertained by comparison with similar agreements without options

5. Significant compliance costs would be involved in obtaining option valuations

6. Negotiation of short terms of limited asset usage that incorporate renewal options could ensure future requirements and minimize balance sheet obligations

\section{No of responses 4 \\ Users Preparers}

37

36

81

83

35

79

35

79

37

29

81

74
Mean $^{2,3}$

(std. dev.)

Users Preparers Diff ${ }^{5}$

\subsection{4}

(0.86)

3.31

(1.04)

$3.29 * *$

(0.83)

3.14

(0.81)

$3.38 * *$

(1.09)

$3.52 * * *$

(0.78)
2.83

(1.06)

$3.71 * * *$

(0.86)

$2.57 * * *$

(1.01)

$2.66 * * *$

(1.00)

$4.03 * * *$

(0.84)

$3.46 * * *$

(0.76) ns

\section{Panel B: Contingent rentals}

Question asked (abbreviated) ${ }^{1 \mathrm{a}}$

To what extent do you agree with the following?

1. No balance sheet recognition of contingent lease rentals; they should be expensed when revenue/profits arise

2. Estimates of probable amounts paid should be recorded on the balance sheet

3. If minimum lease rentals are unrepresentative, the fair value of property rights conveyed should be recognized on the balance sheet

4. Fair value of property rights conveyed can be ascertained by comparison with similar lease agreements excluding the contingency

5. It is incorrect to compare with similar agreements excluding contingency; contingent element restricts asset use making the lease less valuable

\section{No of responses 4 \\ Users Preparers}

39

39

86

86

36

86

35

79

33

76

Mean $^{2,3}$

(std. dev.)

Users Preparers Diff ${ }^{5}$

\subsection{8}

$3.69 * * *$

(1.00)

3.08

(1.01)

$2.48^{* * *}$

(1.00)

2.94

(0.94)

(1.00)

$2.77 * *$

(1.01)

(0.86)

$3.29 * * *$

$3.58^{* * *}$

(0.88)
0.01

0.01

ns

ns

ns

Panel C: Rentals that vary in line with prices

To what extent do you agree with the following?

1. Assets and liabilities should be recognized on basis of rentals applicable at beginning of lease term

2. Assets and liabilities should be recognized on basis of estimates of rentals that will actually be paid

3. Estimates of liabilities arising through rising prices cannot be measured reliably
Question asked (abbreviated) ${ }^{1 \mathrm{a}}$

No of responses ${ }^{4}$ Users Preparers

39

38

38

Notes: See Table 1
Mean $^{2,3}$

(std. dev.)

Users Preparers Diff ${ }^{5}$

$\begin{array}{llll}85 & 3.08 & 3.71 * * * & 0.01\end{array}$

(1.20)

(1.08)

$2.52 * * *$

0.05

(1.07)

3.13

(1.09)

$3.81 * * *$

(1.08)
0.01

ns
(1.17) 


\section{Table 4: Views on the consequences of adopting the G4+1 lease accounting proposals}

Panel A: All assets

\begin{tabular}{|c|c|c|c|c|c|c|c|}
\hline & \multirow[b]{2}{*}{$\begin{array}{l}\text { Question asked (abbreviated) } \\
\text { To what extent do you agree that the } \\
\text { following are direct or indirect } \\
\text { consequences or recording all material } \\
\text { leases on the lessee's balance sheet? }\end{array}$} & \multicolumn{2}{|c|}{ No of responses ${ }^{4}$} & \multicolumn{2}{|c|}{$\begin{array}{c}\text { Mean } \\
\text { (std. dev.) }\end{array}$} & \multirow[t]{2}{*}{$\begin{array}{l}\text { Preparer } \\
\text { rank }^{1 b}\end{array}$} & \multirow[b]{2}{*}{ Diff ${ }^{5}$} \\
\hline & & Users & Preparers & Users & Preparers & & \\
\hline 1. & $\begin{array}{l}\text { Many operating leases would give rise to } \\
\text { assets and liabilities on the balance sheet }\end{array}$ & 38 & 88 & $\begin{array}{c}4.16^{* * * *} \\
(0.55)\end{array}$ & $\begin{array}{c}4.36 * * * \\
(0.59)\end{array}$ & 1 & ns \\
\hline 2. & $\begin{array}{l}\text { Reported measures of gearing would } \\
\text { increase }\end{array}$ & 38 & 87 & $\begin{array}{c}4.13^{* * * *} \\
(0.66)\end{array}$ & $\begin{array}{c}4.18 * * * \\
(0.83)\end{array}$ & 2 & ns \\
\hline 3. & $\begin{array}{l}\text { Users' evaluation of long term finance } \\
\text { commitment of lessees would improve }\end{array}$ & 38 & 86 & $\begin{array}{c}3.89 * * * \\
(0.69)\end{array}$ & $\begin{array}{c}3.38 * * * \\
(1.00)\end{array}$ & 7 & 0.01 \\
\hline 4. & $\begin{array}{l}\text { Users' ability to compare companies } \\
\text { would improve }\end{array}$ & 38 & 85 & $\begin{array}{c}3.76^{* * * *} \\
(0.79)\end{array}$ & $\begin{array}{l}3.27 * * \\
(1.02)\end{array}$ & 9 & 0.05 \\
\hline 5. & $\begin{array}{l}\text { Users would increase their estimates of } \\
\text { risks involved in providing finance to } \\
\text { lessees }\end{array}$ & 39 & 83 & $\begin{array}{c}3.51 * * * \\
(0.76)\end{array}$ & $\begin{array}{c}3.01 \\
(0.93)\end{array}$ & 11 & 0.01 \\
\hline 6. & $\begin{array}{l}\text { Lessee companies may need to } \\
\text { renegotiate their borrowing covenants }\end{array}$ & 37 & 82 & $\begin{array}{c}3.43 * * * \\
(0.77)\end{array}$ & $\begin{array}{l}3.96 * * * \\
(0.81)\end{array}$ & 3 & 0.01 \\
\hline 7. & $\begin{array}{l}\text { Financial statements would reflect the } \\
\text { financial flexibility provided by different } \\
\text { leasing arrangements }\end{array}$ & 37 & 85 & $\begin{array}{c}3.41 * * \\
(0.98)\end{array}$ & $\begin{array}{l}2.77 * * \\
(0.96)\end{array}$ & 15 & 0.01 \\
\hline 8. & $\begin{array}{l}\text { Some lessees would experience a } \\
\text { reduction in credit rating }\end{array}$ & 35 & 81 & $\begin{array}{l}3.40 * * \\
(1.01)\end{array}$ & $\begin{array}{c}3.25 * * * \\
(0.83)\end{array}$ & 10 & ns \\
\hline 9. & $\begin{array}{l}\text { Lease terms would become shorter to } \\
\text { minimize obligations }\end{array}$ & 36 & 83 & $\begin{array}{l}3.33 * * \\
(0.79)\end{array}$ & $\begin{array}{c}3.41 * * * \\
(0.95)\end{array}$ & 6 & ns \\
\hline 10. & $\begin{array}{l}\text { Significant additional administrative } \\
\text { burden }\end{array}$ & 39 & 86 & $\begin{array}{l}3.26 \\
(1.14)\end{array}$ & $\begin{array}{l}3.64 * * * \\
(0.99)\end{array}$ & 5 & ns \\
\hline 11. & Significant additional compliance costs & 39 & 87 & $\begin{array}{l}3.21 \\
(1.08)\end{array}$ & $\begin{array}{c}3.70 * * * \\
(0.95)\end{array}$ & 4 & 0.05 \\
\hline 12. & $\begin{array}{l}\text { Lease finance would become less } \\
\text { attractive }\end{array}$ & 38 & 87 & $\begin{array}{l}3.21 \\
(1.04)\end{array}$ & $\begin{array}{c}3.37 * * * \\
(0.90)\end{array}$ & 8 & ns \\
\hline 13. & $\begin{array}{l}\text { Users' assessments of debt-paying ability } \\
\text { of lessees would not be affected }\end{array}$ & 39 & 84 & $\begin{array}{l}3.10 \\
(0.97)\end{array}$ & $\begin{array}{c}3.01 \\
(0.84)\end{array}$ & 12 & ns \\
\hline 14. & $\begin{array}{l}\text { New assets } \quad \text { would be } \\
\text { purchased/constructed rather than leased }\end{array}$ & 35 & 83 & $\begin{array}{l}2.91 \\
(0.98)\end{array}$ & $\begin{array}{l}2.81 * * \\
(0.77)\end{array}$ & 14 & ns \\
\hline 15. & $\begin{array}{l}\text { Shareholders would reduce their estimates } \\
\text { of lessees' ability to pay future dividends }\end{array}$ & 35 & 81 & $\begin{array}{l}2.80 \\
(0.76)\end{array}$ & $\begin{array}{c}2.62 * * * \\
(0.75)\end{array}$ & 16 & ns \\
\hline 16. & $\begin{array}{l}\text { Significant short-term reduction in UK } \\
\text { investment and leasing volumes, to } \\
\text { reduce perceived high gearing }\end{array}$ & 35 & 81 & $\begin{array}{l}2.63 * * \\
(1.06)\end{array}$ & $\begin{array}{c}2.85 \\
(1.03)\end{array}$ & 13 & ns \\
\hline
\end{tabular}


Question asked (abbreviated) ${ }^{\mathbf{1 b}}$

To what extent do you agree that the following suggested consequences of the new approach apply to the leasing of land and buildings?

1. Recording leased asset brings it within scope of impairment, with advantage of writing off any loss when it occurs not when decision taken to vacate property

2. Advantage of showing increase in value arising from lessee sub-leasing at a higher rent

3. Companies would find it difficult and expensive to estimate the present value of future property rent increases

4. Combined P\&L expense (depreciation and interest) in the early years of a new property lease would substantially exceed market rent

5. Property rental yields may rise to reflect higher risk arising from loss of security of long term tenants

6. Companies would be reluctant to enter long term property leases making it difficult to fund new property development

7. Companies would purchase property rather than lease

\begin{tabular}{|c|c|}
\hline No of responses & $\begin{array}{c}\text { Mean }^{2,3} \\
\text { (std. dev.) }\end{array}$ \\
\hline Preparers & Prepare \\
\hline
\end{tabular}

Preparer

rank $^{1 b}$

Users

Preparers

Diff $^{5}$
34

37

38

31

37

37

35
77

78

84

67

76

2.84

(0.99)

81

2.81

(1.02)

74

3.03

3.00
3.46 ***

$3.24 * * *$

3.94***

$3.55^{* * *}$

(0.86)

2

0.01

ns

6

ns

3.10

5

ns

Notes: See Table 1 


\section{Table 5: Lease accounting alternatives and implementation}

Question asked (abbreviated) ${ }^{1 \mathrm{~b}}$

To what extent do you agree that the following statements regarding lease accounting alternatives?

1. Note disclosure to be accompanied by analysis of lease commitments by asset type

2. Capitalized value of all leases recorded on balance sheet with other material aspects disclosed in a note

3. Introduction of $75 \%$ threshold in finance lease classification

4. Current distinction between finance and operating leases should be maintained

5. Capitalized value of all leases recorded on balance sheet without note disclosure of other material aspects

$\begin{array}{ccc}\text { No of responses }^{4} & \begin{array}{c}\text { Mean }^{2,3} \\ (\text { std. dev. })\end{array} & \begin{array}{c}\text { Preparer } \\ \text { rank }^{1 b}\end{array}\end{array}$

Users Preparers

Users Preparers

Diff $^{5}$

38

$87 \quad 3.76^{* * *}$

$(0.85)$

$3.75 * * *$

(0.93)

39

86

$3.62 * * *$

2.95

$(0.91)$

(1.23)

36

80

2.92

(0.94)

$2.73 * *$

(0.97)

39

86

$2.46^{* * * *}$

3.05

(1.14)

39

86

$2.46 * * *$

(1.23)

(0.82)

$2.27 * * *$

(0.95)

\section{Diff}

ns

0.01

ns

0.05

ns

Panel B: Implementation

Question asked (abbreviated) ${ }^{1 \mathrm{~b}}$

To what extent do you agree that the following statements regarding implementation of new proposals for lease accounting?

1. Immediate implementation of proposals to new and existing leases

2. Transition period with operating lease capitalization required for new leases and disclosure of capitalized value required for existing leases

3. Transition period with the capitalized disclosed and only incorporated in balance sheet at end of transition period

4. Transition period with operating lease only

\begin{tabular}{cccc} 
& \multicolumn{2}{c}{ Mean $^{2,3}$} & Preparer \\
No of responses & 4 & (std. dev.) & rank $^{1 \mathrm{~b}}$ \\
Users & Preparers & Users $\quad$ Preparers &
\end{tabular}

Diff $^{5}$ value of (new and existing) leases capitalization required for new leases
39

39

39

39
88

88

87

88
$3.36 * *$

(1.01)

2.85

(0.99)

2.72

(1.02)

$2.54 * * *$
$(0.97)$
$2.61 * * *$

(1.25)

$2.52 * * *$

(1.14)

$2.56 * * *$

(1.12)

(1.19)
$2.55 * * *$

1

0.01

4

ns

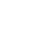

2

ns

Notes: See Table 1 